\title{
SIR FRANCIS CRANE KT. AND DR. WILLIAM DAVISON; PATIENT AND DOCTOR IN PARIS IN 1636
}

\author{
by
}

\section{LAURENCE MARTIN*}

THIS DUAL biographical essay concerns two outstanding men of the seventeenth century, an Englishman and a Scotsman. They made their reputations in very different walks of life and in different countries. Both were protégés of royalty; Sir Francis Crane of James I and Charles I, and William Davison of Charles I and Queen Henrietta Maria, as well as of the kings of France and Poland, to whom he was successively appointed physician. Crane was a courtier, administrator, and man of the world; Davison was a chemist, botanist, and Paracelsian physician. The two were briefly brought together in Paris in 1636 as patient and doctor. Both died in Paris; Crane in 1636 and Davison in 1669.

Nothing is known of the parentage or ancestry of Sir Francis Crane (Fig. 1); neither the date and place of his birth nor his exact age at death are recorded. This is all the more remarkable because he and his relations were prominent people holding appointments in the Court, royal households and State. Thus his only brother, Richard Crane (d. 1645), was Captain and Gentleman of the Privy Chamber in the reign of Charles I and was created a baronet in 1642. His cousin, John Crane (15761661) of Loughton, Bucks., was an Officer of the Admiralty and Surveyor General of Victuals for all ships. He had been a servant of Queen Elizabeth I before becoming Chief Clerk of the Green Cloth to James I, Charles I, and Charles II. Another cousin was John Crane (1571-1652), the Cambridge apothecary and philanthropist who was High Sheriff of Cambridgeshire in 1641 and bore the arms of the Cranes of Suffolk.

Nor is anything known about the early life of Sir Francis before 1606 when it is stated that he was granted the office of Clerk of the Parliaments for life. ${ }^{1}$ But Bond points out that he was only granted a reversion of the office and never succeeded to it because he relinquished the reversion in $1613 .^{2} \mathrm{He}$ became Secretary to Charles, Prince of Wales, in 1612, was knighted at Coventry in 1617, and sat as Member of Parliament for Penrhyn in 1614 and for Launceston in 1624. In 1628 he became the sixteenth Chancellor of the Order of the Garter but, as was then the custom, he was

*Laurence Martin, M.D., F.R.C.P., Honorary Consulting Physician, Addenbrooke's Hospital, Cambridge.

${ }^{1}$ Cal. State papers Dom., 1603-1610, p. 311.

${ }^{2}$ Maurice Bond, 'Clerks of the Parliaments 1509-1953', Eng. hist. Rev., 1958, 73: 78-85, see p. 83 , footnote 15 . 


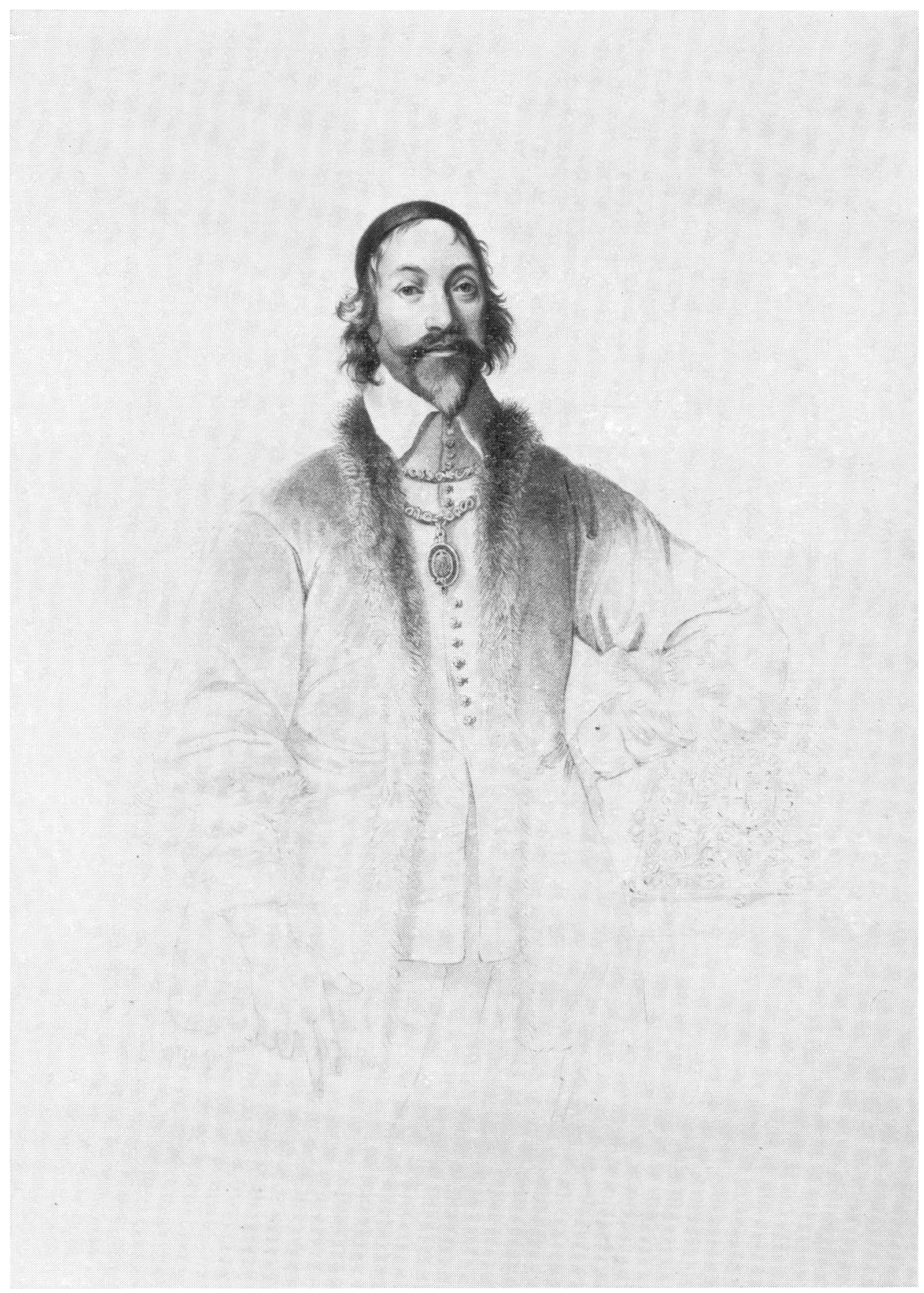

Figure 1.

Engraving from a portrait of Sir Francis Crane by G. Jamesone (1586-1664). Engraver unknown. Sir Francis wears the Chancellor's badge of the Order of the Garter, and the ceremonial embroidered purse for the seals is seen below his left arm. (Reproduced by courtesy of the Trustees of the British Museum.) 


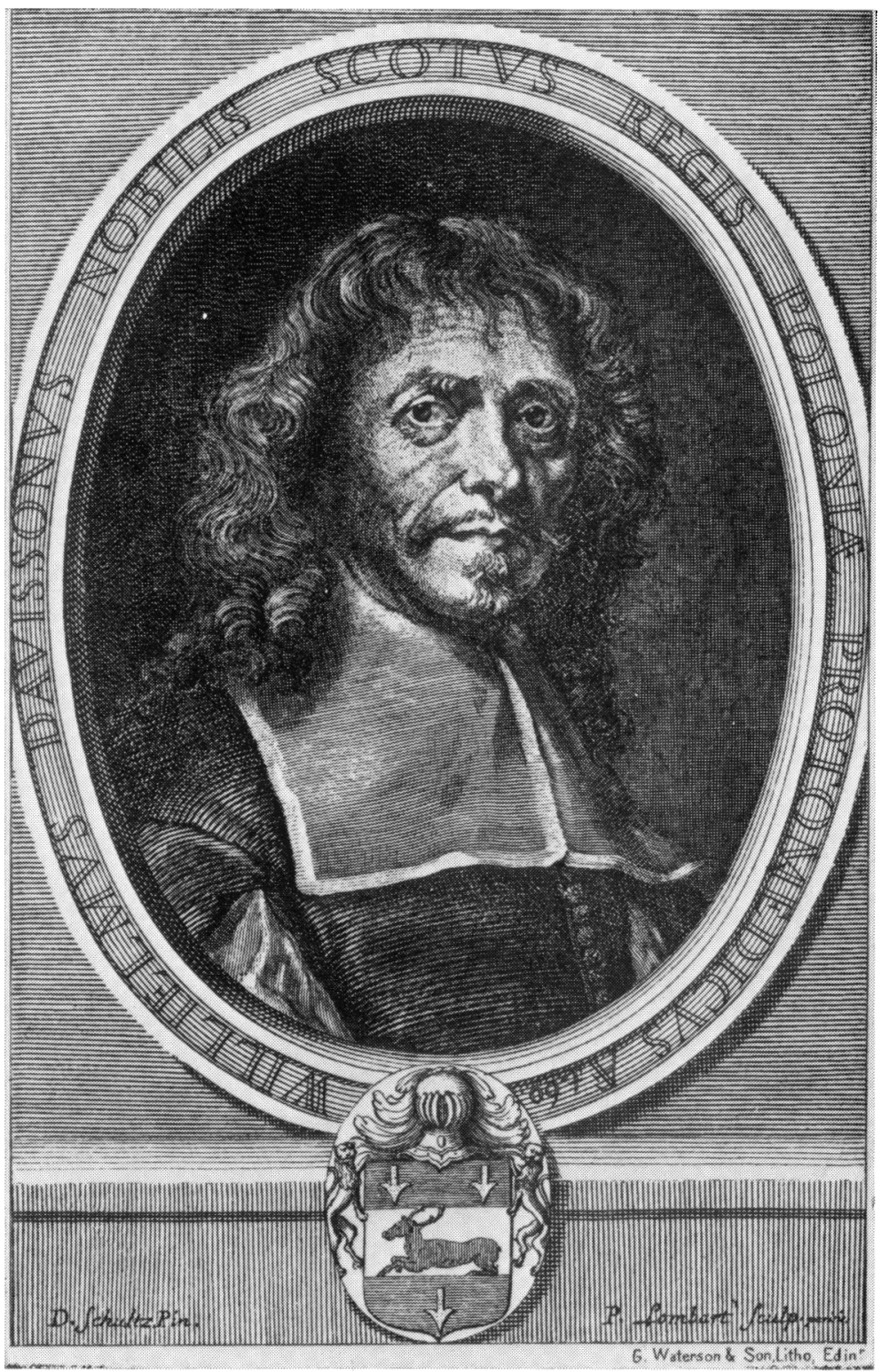

Figure 2.

Engraving by P. Lambart (1620-1681) of the portrait of Dr. William Davison painted in 1662 by Daniel Schultz of Dantzig (1620-1686). (From Proceedings of the Society of Antiquaries of Scotland, 1875, 10: Plate 7. Reproduced by courtesy of the Cambridge University Library.) 


\section{Short Articles}

not himself a Knight Companion. It is stated in the Dictionary of national biography and elsewhere that he was the last lay Chancellor of the Order, but in fact he was succeeded by three laymen before the office was restored to the Bishops of Salisbury in 1669. ${ }^{3}$ Sir Francis built the Mortlake Tapestry Manufactory in 1619 and became its first Director under the patronage and financial support of James I, the Prince of Wales, and George Villiers, Marquis (and later Duke) of Buckingham. When Charles I came to the throne he owed Sir Francis $£ 6,000$ for three suites of gold tapestry and, as security for this and further debts, he mortgaged the estates of Grafton and Stoke Park in Northamptonshire to him in 1628 and 1629. Under the able direction of Sir Francis, and with Francis Cleyn, who was appointed Limner and Designer in 1623, the Mortlake manufactory flourished and the tapestries it produced were as good or better than any in Europe.

In March 1636 Sir Francis was granted permission to go to Paris for treatment of stone in the bladder. He could, presumably, have been treated in London, as Robert Murrey had been appointed Lithotomist to St. Bartholomew's Hospital in 1612,4 and by 1658, when Samuel Pepys was cut by Thomas Hollyer of St. Thomas's Hospital, the operation was by no means uncommon. ${ }^{5}$ But the incidence of stone was higher in France than in England hence, in 1636, the French experience of lithotomy may well have been greater. Dr. Martin Lister, when visiting Paris in 1698, commented that "Another popular Disease here is the Stone and there are Men well practised in the Cutting for it." He witnessed lithotomies by the notorious Frère Jacques an itinerant monk-lithotomist and was "put into some disorder with the cruelty of the operation." He also saw at the La Charité and Hôtel Dieu hospitals the wired chests full of stones which had been removed. In that at La Charité was “. . . one which exceeds all belief; it was cut from a monk who died in the very operation; it is as big as a child's head." 6 Sir Francis sailed from Rye for Dieppe with six servants on 18 March 1636 and reached Paris in the evening of the 24th. Lord John Scudamore, the English Ambassador, reported to Sir Francis Windebank, the Secretary of State, on 25 March that "Sir Francis Crane came to Paris last night and looks very well in the face this morning. Will signify to Dr. Davison his Majesty's gracious favour. He [Charles I] has been rightly informed concerning the worth of this man and the benefit his Majesty's subjects receive by him."'

William Davison, Davissone or Davidson, was born about 1593 at Ardmakrone in Aberdeenshire, the son of Duncan Davisonne and Jonet Forbes, daughter of William Forbes, baron of Pitsligo. ${ }^{8} \mathrm{He}$ claimed descent from several noble Scots families and, on the engraving of his portrait (Fig. 2) he is described as "Nobilis Scotus". He

\footnotetext{
${ }^{3}$ Elias Ashmole, The institution, laws and ceremonies of the most noble order of the Garter, London, J. Macock for Nathaneal Brooke, 1672, p. 719.

4A. W. Badenoch, 'Cutting for stone', St. Bart's. Hosp. J., 1955, 59: 90-95.

${ }^{5}$ Sir Eric Riches, 'Samuel Pepys and his stones', Ann. roy. Coll. Surg. Eng., 1977, 59: 11-16.

- Martin Lister, A journey to Paris in the year 1698, 2nd ed., London, Jacob Tonson, 1699, pp. 232236.

7 Cal. State papers Dom., 1635-36, p. 321, see also State papers, Foreign: France, SP78/100.

8 John Small, 'Notice of William Davidson, M.D. (Guliemus Davissonus) first professor of chemistry and director of the jardin des plantes, Paris, afterwards physician to the King of Poland', Proc. Soc. Antiquaries of Scotland, 1875, 10: 265-280.
} 


\section{Short Articles}

entered Marischal College, Aberdeen, in 1614 and graduated M.A. in 1617, there being no M.D. degree at that time. He emigrated to Paris shortly afterwards, where he taught chemistry. He must have qualified in medicine and pharmacy, possibly at Montpellier, as he subsequently practised as a physician and apothecary. He also gave lectures and practical demonstrations on chemical medicines such as antimonial, mercurial, and other drugs favoured by the Paracelsians. He was much in demand by the English and Scottish communities in Paris and numbered the English Ambassador and Thomas Windebank, son of the Secretary of State, among his patients. ${ }^{9}$

It is not known who operated upon Sir Francis Crane on the morning of 18 April 1636. Lord Scudamore duly reported to Secretary Windebank that "Sir Francis Crane was cut this morning. The stone is almost as big as an ordinary hen's egg and of that shape, and being rough well near all over. He went to it cheerfully and so endured it." The operation was evidently carried out with great rapidity for "They were not in the operation longer than the Secretary may judge Lord Scudamore has been writing thus far. Seven hours after the operation Sir Francis spoke heartily and said he had now lived so many hours, meaning that his freedom from the former pain made him think his present [state] being as different as life [from] that which was not life or worse. But when urine passeth through the wound his payne is great. Dr. Davison thinks him as well as could be expected he should be now."10 But, unhappily, things did not continue well and some ten weeks later, on 27 June, the Ambassador had to inform Windebank, "Yesterday evening about ten o'clock Sir Francis departed. In the whole course of this disease he has behaved himself like a stout and humble Christian and member of the Church of England. His nephew Mr. [William] Crane ${ }^{11}$ that is a Fellow of Trinity College, Cambridge lays fault upon the Surgeon. The wound grew to an ulcer and gangrene. His body will be carried to England."12 Sir Francis was evidently well aware that he would not recover. Three days before he died he added a codicil to his will, "At Paris the $23^{\text {th }}$ of June English Stile 1636" in which he expressed the wish to be buried at Woodrising in Norfolk, where he owned the manor, and advised his wife to leave Grafton and go to live there. He ended the message and codicil "- -your dyeing husbande-Fr Crane."13

Sir Francis was duly buried at Woodrising Church and a memorial in the sanctuary floor is described by Steer ${ }^{14}$ as follows: "Ledger stone inlaid with brass oval engraved with a fine achievement of arms: Per bend [azure] and [or], for Crane; crest on a wreath $-A$ pair of wings elevated and addorsed, with a scroll running through them, thereon Ad Virtus Astra. The shield is encircled by a chain from which hangs the badge of the Chancellor of the Most Noble Order of the Garter. The stone is inscribed, within

- Cal. State papers Dom., 1637, pp. 184, 206.

10 Ibid., 1636, p. 372, see also State papers, Foreign: France, SP78/100.

11 W. W. Rouse Ball and J. A. Venn, Admissions to Trinity College, Cambridge, 5 vols., London, Macmillan, 1913, vol. 2, p. 316. Also eldest son of John Crane of Loughton (p. 346), married Frances Bond, niece and adopted heiress of Sir Francis Crane.

12 Cal. State papers Dom., 1636-37, p. 25, see also State papers, Foreign: France, SP78/101.

$18 \mathrm{John}$ Matthews and George F. Matthews (editors), Year books of probates (from 1630), abstracts of probate acts in the prerogative court of Canterbury, 8 vols., London, 1903, vol. 2 (1635-39), p. 87.

${ }_{14}$ Francis W. Steer, Woodrising Church, Norfolk, and notes on the Southwell and other families connected with the parish, Diocese of Norwich, 1959, p. 12 and plate XI. 


\section{Short Articles}

a frame- $S^{r}$ FRANCIS CRANE $\mathbf{K}^{\mathbf{n}}$; CHANCELLOR OF/ THE MOST NOBLE ORDER OF THE GARTER/ (AGED ABOUT 57 YEARS) DYED THE 26/ DAYE OF IVNE AT PARIS IN FRANCE FRO/ WHENCE HIS BODY WAS BROVGHT AND/ BVRIED IN THIS PLACE THE $10^{\text {th }}$ DAYE OF IV/LY FOLLOWING ANO DNI 1636".

In his will Sir Francis left $£ 500$ for the rebuilding of St. Paul's Cathedral and money to build houses for, and to maintain, five additional Poor Knights at Windsor Castle (known since 1833 as Military Knights of Windsor). ${ }^{15}$ On 18 July 1636 Sir Kenelm Digby, a friend both of Sir Francis Crane and Dr. Davison, who was in Paris at the time, wrote to the Secretary of State and enclosed a statement of Sir Francis's case and "the fatall issue of his cutting penned by Dr. Davison and signed by him and another physician of the Kinge's [of France] that attended him all the while." Unhappily, the medical statement has not survived and it is uncertain as to which Secretary of State Digby's letter was addressed. ${ }^{16}$ But Digby had attended the dissection after death at which it was apparent that there could have been no hope of recovery. It may be presumed that chronic sepsis or surgical hazard-or bothhad produced the ulceration and gangrene which must have led to a horrible death. In his letter to the Secretary of State Digby paid his tribute to Sir Francis as follows: "It was God's will to take unto him after long sufferance and patience as generous a gentleman and that as constant a heart as I have bin acquainted withall." The letter continued with a lengthy appreciation of Davison's unremitting care and attention to Sir Francis which he asks may be brought to the king's notice. Because Davison had said "so little to set himself forth" in the statement of the case, Digby, who was a daily witness of all his proceedings, felt that he would be "much to blame if, to supplye his shortnesse I should not expresse some part of what I know . . . This much then I must say for him: that never was so much care and tendernesse by any physitian expressed to a languishing patient, as was by him to this noble gentleman. So long a time of durance might well have bin deemed sufficient to weare out the patience and dulle the affections of a man that had not engagements of a longer date and deeper than Dr. Davisson had to Sir Fra: Crane. But he continued his to the very last and even after all hopes of life were faded, he continued his perpetual attendance to the neglect of all his other affaires, so as in three months time I think he was scarce one houre in the day or night out of his presence ... and besides, failed of what went much nearer his heart, $w^{\text {ch }}$ was the looking to his wife and children when they .... and all the rest of his family were runne over $\mathrm{w}^{\text {th }}$ the small pockes whiles he remained about Sir Francis ...... And therefore yr Ho: will do nobly and generously (wch is yr delight) to let his Majesty understand how he hath behaved himselfe in this occasion."

After 1636 Davison continued his remarkable career. In 1644 a parliamentary decree forbade foreign physicians to practise in Paris but, with the help of Queen

${ }^{15}$ E. H. Fellowes, Military Knights of Windsor 1315-1944, Windsor, Oxley \& Son for the Dean and Canons of Windsor, 1944, pp. xxxvii-xxxix and li-lii.

${ }^{16}$ Cal. State papers Dom., 1636-37, p. 56. gives the addressee as Secretary Windebank but in State papers, Foreign: France SP78/101, fol. 265, the addressee is given as "Coke". The medical report cannot be traced in the State papers nor in those of either possible recipient. 


\section{Short Articles}

Henrietta Maria and his friend François Vautier, First Physician to the French King, Davison was appointed Physician to the King of France and so evaded the decree. Vautier was also Superintendent of Le Jardin du Roi, the Royal Botanical Garden of Paris, which was opened in 1640, and Davison was appointed to a now Chair of Chemistry there in 1647. He also gave lectures on botany, and John Evelyn, who attended one on 21 October 1649, wrote: "I went to heare Dr. D'Avinson lecture in ye physical garden and see his laboratorie, he being Prefect of ye excellent Garden and Professor Botanicus."17 But Davison was too successful for a foreigner and his enemies stirred up religious and medical intrigues against him, so that in 1651 he was forced to resign his appointments. However, his friends came to his rescue again and he was appointed Physician (Senior Archiatrus et Chymicus) to King John Casimir and Queen Marie Louise of Poland, as well as Keeper of the Royal Garden in Warsaw. But his work and studies were greatly interrupted by constant changes of residence due to the Swedish war, during which he accompanied the queen. He was at last able to return to the Royal Garden in 1667 but the queen died in that year. Davison subsequently visited Aberdeen in 1668 before returning to Paris in 1669 where he is believed to have died soon afterwards.

A full account of Davison's career and numerous writings on chemical and quasiphilosophical subjects has been given by Read, ${ }^{18}$ who pointed out that he was the first Professor of Chemistry in France, the first Scots Professor of Chemistry, and the first native of the British Isles to hold such an appointment. His first and most important work was Philosophia pyrotechnica seu curriculus chymiatricus, originally printed in four parts in Paris during 1633-35. Several further editions followed and the work was one of the earliest textbooks of chemistry. His final work was printed in Aberdeen during his last visit and was published in Dantzig in 1668 under the Paracelsian pseudonym of "Theophrastus Scotus". It was entited Theophrasti Verdici Scoti Doctoris Medici seu Plicae numero morborum and was of medical interest, being concerned mainly with a condition of dense matting of the hair, which sometimes formed a solid pigtail, known as Plica Polonica or Polish Plait. It was believed to be peculiar to Poland but Davison opposed this view. He believed that all the symptoms of it might be attributed to other maladies. He was proved to be correct; in that the disease later became recognized as one of neglect and dirt superimposed upon pediculosis capitis. In 1893 Radcliffe Crocker wrote: "Plica, which may be defined as entangling of the hair occupied at one time a comparatively important place in works on skin diseases ... but since the mysterious plica polonica was proved to be nothing more than the product of neglect and the matting due to inflammatory exudation, excited by innumerable pediculi agglutinating the hair together, the term is scarcely mentioned in dermatological works." 19

Davison was more distinguished as a chemist than as a botanist but not enough is known about his medical work to assess him as a physician. The foregoing information

${ }^{17}$ William Bray (editor), Memoirs illustrative of the life and writings of John Evelyn, comprising his diary from the year 1641 to 1705-6 and a selection of his familiar letters, 2nd ed., 2 vols., London, John \& Arthur Arch, 1819, vol. 1, p. 240.

18 John Read, William Davidson of Aberdeen. The first British professor of chemistry, tercentenary memorial lecture delivered on 26 November 1948, Aberdeen University Press, 1951.

${ }^{10}$ H. Radcliffe Crocker, Diseases of the skin, 2nd ed., London, Lewis, 1893, pp. 775, 868. 


\section{Short Articles}

concerning Sir Francis Crane and the letter from Sir Kenelm Digby appear to be the only available anecdotes of Davison's clinical activities. But they do at least show that when the vis medicatrix naturae failed him, he knew full well how to use that last and most valuable therapy-tender, loving care. If his reputation as a physician also rested upon that in other cases, it would have been high.

\section{SUMMARY}

An account is given of a brief patient-doctor relationship in Paris in 1636 between Sir Francis Crane Kt., and Dr. William Davison. The former was Chancellor of the Order of the Garter and Director of the Mortlake tapestry works; the latter a chemist, botanist, and Paracelsian physician. Sir Francis died some ten weeks after an operation for stone in the bladder (by an unknown surgeon) and was attended by Davison. The careers of both men are summarized and tributes paid to them. Despite their accomplishments, they were not well known. Sir Francis received high praise for the fortitude with which he endured a ghastly operation and a lingering death, and Davison great commendation for his unremitting care and attendance on Sir Francis. Davison later became physician to the kings of France and Poland and the first British professor of chemistry. He is believed to have died in Paris in 1669. 